Article

\title{
Episode-Based Analysis of Size-Resolved Carbonaceous Aerosol Compositions in Wintertime of Xinxiang: Implication for the Haze Formation Processes in Central China
}

\author{
Guangxuan Yan ${ }^{1, *}$, Jingwen Zhang ${ }^{1}$, Puzhen Zhang ${ }^{1}$, Zhiguo Cao ${ }^{1}$, Guifen Zhu ${ }^{1}$, \\ Zirui Liu $2, *(1)$ and Yuesi Wang $2,3,4$
}

1 Key Laboratory for Yellow River and Huai River Water Environment and Pollution Control, Henan Key Laboratory for Environmental Pollution Control, School of Environment, Henan Normal University, Xinxiang 453007, China; zjwwwen0915@163.com (J.Z.); jumpzhenn@163.com (P.Z.); wq11ab@163.com (Z.C.); gfzhu617@163.com (G.Z.)

2 State Key Laboratory of Atmospheric Boundary Layer Physics and Atmospheric Chemistry, Institute of Atmospheric Physics, Chinese Academy of Science, Beijing 100029, China; wys@mail.iap.ac.cn

3 Center for Excellence in Regional Atmospheric Environment, Institute of Urban Environment, Chinese Academy of Science, Xiamen 361021, China

4 School of Resource and Environment, University of Chinese Academy of Science, Beijing 100049, China

* Correspondence: xuanxuaneeee@163.com (G.Y.); liuzirui@mail.iap.ac.cn (Z.L.); Tel.: +86-37-3332-5971 (G.Y.); +86-10-6236-2389 (Z.L.)

Received: 20 April 2020; Accepted: 12 May 2020; Published: 19 May 2020

check for updates

\begin{abstract}
To provide a comprehensive understanding of carbonaceous aerosol and its role in the haze formation in the Central Plains Urban Agglomeration of China, size-segregated particulate matter samples $\left(\mathrm{PM}_{1}, \mathrm{PM}_{2.5}\right.$ and $\left.\mathrm{PM}_{10}\right)$ were continually collected from 20 December 2017, to 17 January 2018, in Xinxiang, the third largest city of Henan province. The results showed that the mean mass concentrations of $\mathrm{PM}_{1}, \mathrm{PM}_{2.5}$ and $\mathrm{PM}_{10}$ were $63.20,119.63$ and $211.95 \mu \mathrm{g} \cdot \mathrm{m}^{-3}$, respectively, and the organic carbon (OC) and elemental carbon (EC) were $11.37(5.87), 19.24(7.36)$, and $27.04(10.27) \mu \mathrm{g} \cdot \mathrm{m}^{-3}$, respectively. Four pollution episodes that were categorized by short evolution patterns (PE1 and PE3) and long evolution patterns (PE2 and PE4) were observed. Meteorological condition was attributed to haze episodes evolution pattern. Carbonaceous components contributed to PE1 and PE2 under drier condition through transportation and local combustion emission, while they were not main species in PE3 and PE4 for haze explosive growth under suitable $\mathrm{RH}$, whatever for the short or long evolution pattern. The atmospheric self-cleaning processes were analyzed by a case study, which showed the wet scavenging effectively reduced the coarse particles with a removal rate of $73 \%$, while it was not for the carbonaceous components in fine particles that is hydrophobic in nature. These results highlight that local primary emissions such as biomass combustion were the important sources for haze formation in Central China, especially in dry conditions.
\end{abstract}

Keywords: PM; particle size; carbonaceous compositions; haze episode; wet scavenging

\section{Introduction}

The frequent outbreaks and unprecedentedly high particulate matter (PM) concentrations of haze pollution during winter in China has drawn worldwide attention. The health hazardous of PM is size-dependent [1,2], due to its inhalable and adverse effects on the respiratory and cardiovascular system [3]. Besides, distinctive physical or chemical processes are associated to particle size [4,5], especially for the chemical components of a given size, such as carbonaceous species [6], which are 
closely related to a variety combustion processes and their secondary transformation [7-9]. However, the unpredicted temporal and spatial variations in PMs' atmospheric dynamics makes each PM pollution event totally different, even if one pollution event contains the same chemical components as another. Therefore, insight into the concentration of PM size distribution and carbonaceous components are crucial to recognize the influence of the physical and chemical development of aerosol properties during the haze formation process [10].

The temporal pollution characteristics and source apportionment of haze in winter have been extensively reported in recent few years in China (e.g., [11-13]). For example, the peak value of $\mathrm{PM}_{10}$ (aerodynamic diameter $10 \mu \mathrm{m}$ and smaller) appeared in spring in northwest area of China, such as Yulin [11], because of the frequent sand storms in Asia. In comparison, $\mathrm{PM}_{2.5}$ and $\mathrm{PM}_{1}$ (aerodynamic diameter 2.5 or $1 \mu \mathrm{m}$ and smaller, respectively) showed similar seasonal variations with high value in winter in most cities of China [12]. It seems to be more complex for PM diurnal variations. A bimodal pattern was observed in most cities of north China due to morning and evening rush hour. A unimodal pattern associated with morning rush hour was observed in the central aera. While no clear pattern was observed in south China [13]. Therefore, the underlying aerosol formation mechanisms are so complicated that no universal controlling measurement could be used to mitigate PM fast and effectively. At present, various analogy methods aiming to comprehensively understand the haze formation mechanism and processes had been reported in previous studies, but haze-episode-based analysis was more effective to unveil the nature and differences between each haze pollution. For example, fine PM is the main contributor of the two most serious haze pollution episodes in eastern China in winter [14]. By further categorizing these into wet and dry haze, the key chemical species was attributed to sulfate in wet haze episodes and nitrate in dry haze episodes in Changzhou, a developed city in eastern China [15]. No doubt that the triggers are highly episode-dependent, especially for the secondary aerosol formation process in atmospheric PMs. Usually, carbonaceous aerosols constitute a substantial fraction of the atmospheric particles in China, accounting for approximately $20-50 \%$ of the $\mathrm{PM}_{2.5}$ mass [16-18], even higher in $\mathrm{PM}_{1}$ [19]. The Carbonaceous aerosols could change radiative forcing, then result in climate change. In addition, exposed in the toxic carbonaceous species longer, such as polycyclic aromatic hydrocarbons (PAHs) and polychlorinated biphenyls (PCBs), have the potential to increase human carcinogenic risk [20]. It is noteworthy that most carbonaceous species are anthropogenic, which could be divide into organic carbon (OC) and elemental carbon (EC). EC released directly through the combustion process is the main light-absorbing fraction in the atmosphere and plays an important role in reducing visibility and aerosol radiation forcing [21]. One the other hand, OC is derived not only from primary emissions which is regarded as primary organic carbon (POC) such as coal burning, traffic and biomass burning [22], but also from secondary organic carbon (SOC) formed by its precursors through atmospheric chemical transformation [23]. Variations in secondary organic carbon (SOC) and element carbon [24] were commonly attributed to atmospheric secondary formation and primary emission. Therefore, analyzing variations in size-dependent carbonaceous components with aux parameters on a basis of haze episodes event might facilitate to comprehensively understand each haze formation process.

Xinxiang is the third largest city of the Henan province, which is a hotspot area of severe haze pollution in North China with the air quality index (AQI) value frequently exceeding 500 in recent years, approximately double 300, the highest value of National Ambient Air Quality Standard of China (NAAQS, GB 3095-2012). Previous studies conducted at Xinxiang have demonstrated the seasonal characteristics of $\mathrm{PM}_{2.5}$ mass concentration and its chemical components, and subsequently speculated about the potential sources $[25,26]$. However, $\mathrm{PM}_{1}$ and $\mathrm{PM}_{10}$ have been seldom reported. Moreover, it is still a challenge for local government to further mitigate PM's mass concentration in the following Five-Year Plan, $60 \%$ of days were clean $\left(\mathrm{PM}_{2.5}\right.$ and $\mathrm{PM}_{10}$ less than 75 and $150 \mu \mathrm{m} \mathrm{m}^{-3}$, respectively, NAAQS, GB 3095-2012), unless we can understand each haze episode or a same type of haze episodes as much as possible. The source-related, size-segregated mass concentrations and their carbonaceous 
components, and dynamic relationships among them may give us clues on the underlying mechanism for each haze episode. Unfortunately, it remains unclear. Therefore, a monthly field measurement was conducted in Xinxiang from December 2017 to January 2018, with the following expectation: (1) to illustrate the characteristics of mass concentration and the carbonaceous components in $\mathrm{PM}_{1}, \mathrm{PM}_{2.5}$ and $\mathrm{PM}_{10}$; (2) to interpret the underlying processes of haze formation in different haze episodes.

\section{Materials and Methods}

\subsection{Site Description and Sampling}

The winter sampling campaign was conducted on the top of Tianjiabing teaching building ( $30 \mathrm{~m}$ above the ground) the campus of Henan Normal University ( $35^{\circ} 19^{\prime} 29^{\prime \prime} \mathrm{N}, 113^{\circ} 54^{\prime} 27^{\prime \prime} \mathrm{E}$; Figure 1.).

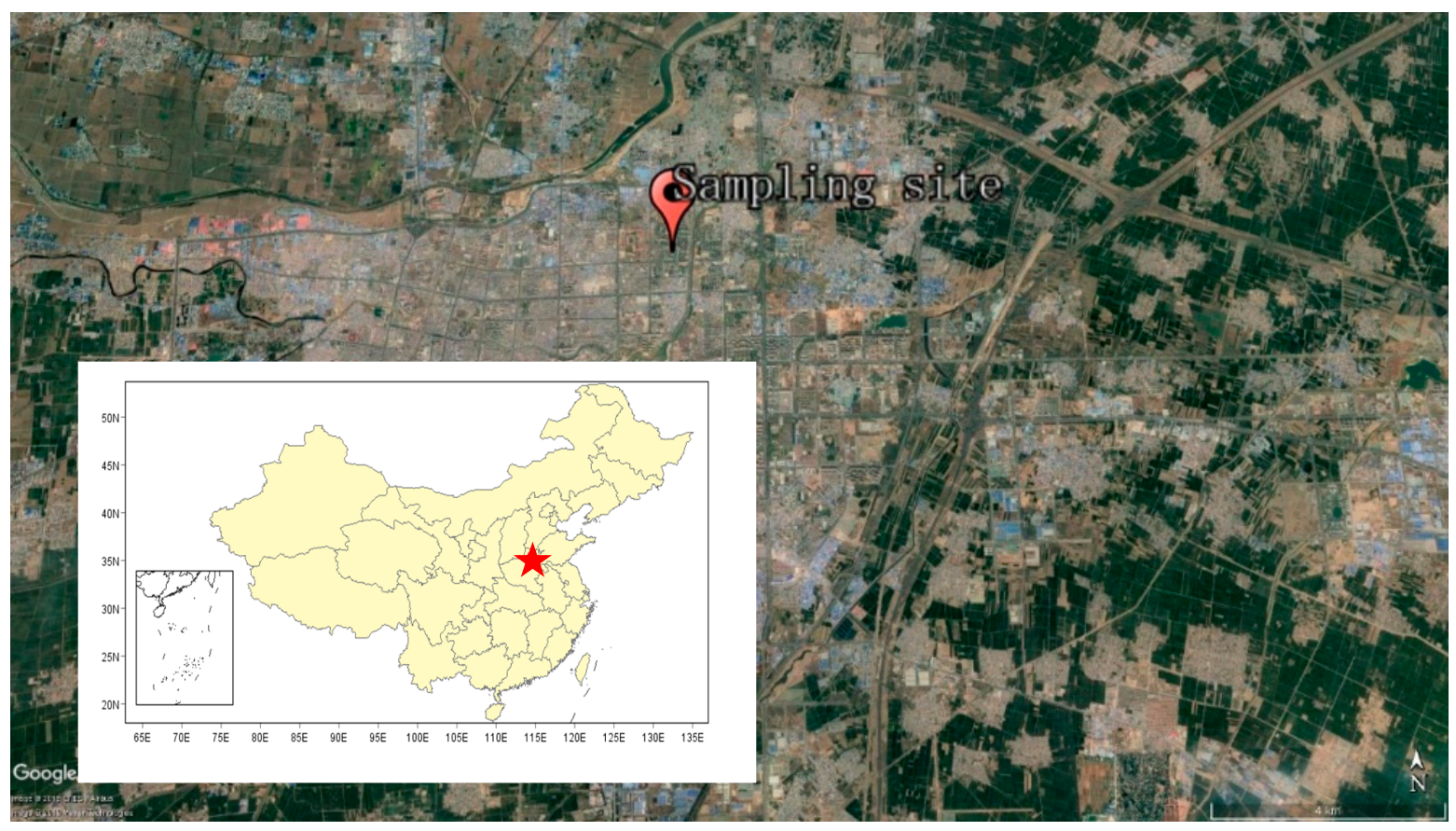

Figure 1. Location of sampling site in Xinxiang.

$\mathrm{PM}_{1}, \mathrm{PM}_{2.5}$ and $\mathrm{PM}_{10}$ samples were simultaneously collected using three mid-volume air samplers at a rate of $100 \mathrm{~L} / \mathrm{min}$ (TH-150C; Tianhong Company, Wuhan, China). In order to avoid flow rate decrease due to too much particle mass accumulated in the filter, two filter samples for each particles size were collected onto pre-baked $\left(450{ }^{\circ} \mathrm{C}, 4.5 \mathrm{~h}\right)$ quartz fiber filters $(\Phi 90 \mathrm{~mm}$, Pall) every day from 08:00 to 19:30 in the daytime and from 20:00 to 07:30 in the following day for the nighttime, respectively; thus, a total of 87 aerosol samples were collected from 20 December 2017 to 17 January 2018. Before sampling, the filters were conditioned at $25 \pm 0.5{ }^{\circ} \mathrm{C}$ and $50 \pm 2 \%$ relative humidity for $48 \mathrm{~h}$ using a microbalance. All the filters were weighted using a microbalance with a resolution of $10 \mu \mathrm{g}$ (XPE205; Mettler-Toledo, Switzerland) before and after sampling. After that, samples were kept in a deep freezer at $-20^{\circ} \mathrm{C}$ until chemical analysis.

\subsection{Measurement}

The OC and EC were determined on a $0.296-\mathrm{cm}^{2}$ rounded quartz filter punch through the DRI Model 2001 Thermal/Optical Carbon Analyzer with IMPROVE_A (Interagency Monitoring of Protected Visual Environment) protocol. The quartz filters were heated in a non-oxidizing helium (He) tube in four temperature gradients $\left(120,250,450\right.$ and $\left.550{ }^{\circ} \mathrm{C}\right)$ to analyze the OC1, OC2, OC3 and OC4, respectively. Then, the temperature was raised stepwise to 550,700 and $800{ }^{\circ} \mathrm{C}$ with $2 \%$ oxygen $\left(\mathrm{O}_{2}\right)$ 
added, in order to analyze the EC1, EC2 and EC3, respectively. The gas generated under the above temperature gradients was oxidized to $\mathrm{CO}_{2}$ via the oxidation furnace $\left(\mathrm{MnO}_{2}\right)$, converted to $\mathrm{CH}_{4}$ under the reduction environment, and the carbon content was determined using a flame ion detector (FID). The pyrolysis OC [27] was defined as the carbon that combusted after the initial introduction of oxygen and before the laser reflectance signal achieved its original value [17], and the OP was assigned to the OC fraction. According to the IMPROVE_A protocol, Total carbon (TC) was defined as OC + EC, $\mathrm{OC}$ was defined as $\mathrm{OC} 1+\mathrm{OC} 2+\mathrm{OC} 3+\mathrm{OC} 4+\mathrm{OP}$, and EC was defined as EC1 + EC2 + EC3-OP. According to the study conducted by Han, Cao [28], Char-EC is defined as EC1-OP, and Soot-EC is defined as EC2 + EC3. Standard gas was used to calibrate the instrument every day, before and after the sample analysis, and test the instrument blank. One of every 10 samples was randomly selected for repeated testing. If the relative deviation of the sum of the EC and OC repeatedly tested is less than $5 \%$, and if OC and EC are less than 10\% [29], the sample analysis result is proven to be effective.

\subsection{Backward Trajectories}

The 48-h air mass backward trajectories that reached the sampling site $\left(35^{\circ} 19^{\prime} 29^{\prime \prime} \mathrm{N}, 113^{\circ} 54^{\prime} 27^{\prime \prime} \mathrm{E}\right)$ were calculated using the National Oceanic and Atmospheric Administration (NOAA) HYSPLIT-4 model. The meteorological data $\left(1^{\circ} \times 1^{\circ}\right.$ latitude-longitude horizontal resolution) introduced into the TrajStat software was acquired from the Global Data Assimilation System (ftp://arlftp.arlhq.noaa. gov/pub/archives/gdas1/). The 48-h air mass back trajectories were calculated at a height of $500 \mathrm{~m}$ for every sampling day, starting at 00:00. The cluster analysis was based on the 48-h backward trajectories, which were categorized into four clusters for each season.

\subsection{POC and SOC}

EC is inert in the atmosphere, and might be a tracer for POC [30]. Due to the lack of an analytical technique for directly quantifying the atmospheric concentrations of POC and SOC, the OC/EC minimum ratio method, which relies mainly on the ambient measurement of $\mathrm{OC}$ and $\mathrm{EC}$, has received widespread application [31]. However, this approach can only be employed when the ratio of $(\mathrm{OC} / \mathrm{EC})_{\min }$ can be assumed to remain reasonably constant during the sampling campaign [32]. Furthermore, the meteorology remained constant during the sampling period. Hence, the following Equations (1) and (2) can be obtained for the semi-quantitative estimation of POC and SOC:

$$
\begin{gathered}
\mathrm{POC}=\mathrm{EC} \times\left(\frac{\mathrm{OC}}{\mathrm{EC}}\right)_{\min }{ }^{\prime} \\
\mathrm{SOC}=\mathrm{OC}-\mathrm{EC} \times\left(\frac{\mathrm{OC}}{\mathrm{EC}}\right)_{\min }{ }^{\prime}
\end{gathered}
$$

where $(\mathrm{OC} / \mathrm{EC})_{\min }$ is the minimum OC/EC ratio of the ambient aerosol.

\section{Results and Discussion}

\subsection{Mass Concentrations of PM and Meteorological Condition}

Figure 2 depicted the temporal variations of the mass concentrations of $\mathrm{PM}_{1}, \mathrm{PM}_{2.5}$ and $\mathrm{PM}_{10}$ in the winter of 2017. The daily mean mass concentrations were 63.20 (range of 15.05 to 146.79$) \mu \mathrm{g} \cdot \mathrm{m}^{-3}$ for $\mathrm{PM}_{1}, 119.63$ (range of 19.62 to 248.06 ) $\mu \mathrm{g} \cdot \mathrm{m}^{-3}$ for $\mathrm{PM}_{2.5}$ and 211.95 (range of 73.34 to 466.41 ) $\mu \mathrm{g} \cdot \mathrm{m}^{-3}$ for $\mathrm{PM}_{10}$, respectively, which decreased by approximately $50 \%$ compared with those reported in the wintertime of 2015 and 2016 (224 and $223 \mu \mathrm{g} \cdot \mathrm{m}^{-3}$, respectively). Nevertheless, $69 \%$ of the sampling days were still recognized as polluted days, with a daily average $\mathrm{PM}_{2.5}$ exceeding $75 \mu \mathrm{g} \cdot \mathrm{m}^{-3}$, and there were nine days with a daily average $\mathrm{PM}_{2.5}$ exceeding $150 \mu \mathrm{g} \cdot \mathrm{m}^{-3}$. This indicated it was still heavily polluted and necessary to further mitigate in the future. 


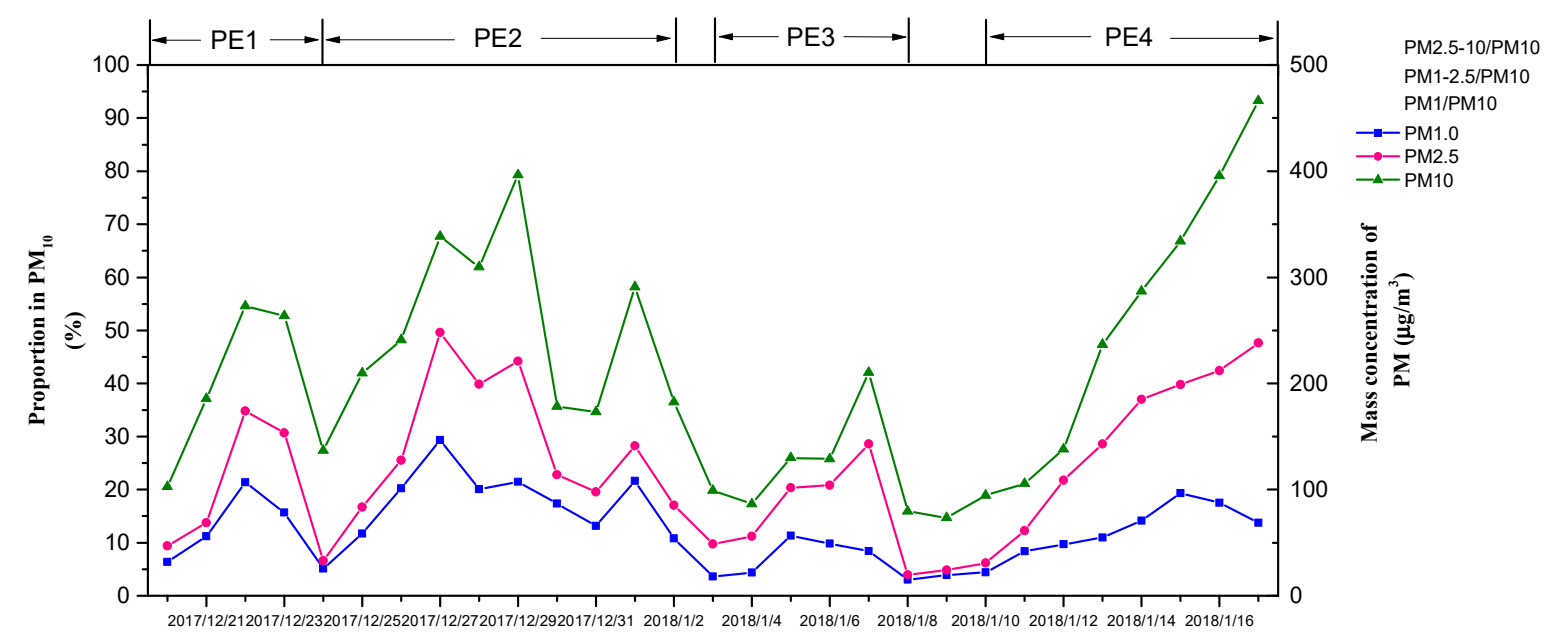

Figure 2. Concentration of particle mass in $\mathrm{PM}_{1}, \mathrm{PM}_{2.5}$ and $\mathrm{PM}_{10}$.

It has been widely accepted that specific meteorological conditions facilitate haze formation, such as high relative humidity (RH), low wind speed (WS) and temperature inversion condition, especially in wintertime in north China [33]. High RH is favored by atmospheric chemical reactions in the dry season, and then accelerates the $\mathrm{PM}_{2.5}$ retention in low WS or temperature inversion conditions [34]. Accordingly, in the present study, the mean RH and WS in the periods of $\mathrm{PM}_{2.5}$ exceeding 150 were $65 \%$ and $1.1 \mathrm{~m} \cdot \mathrm{s}^{-1}$, respectively (Figure S1). This is consistent to other studies in Zibo (WS of $1.1 \mathrm{~m} \cdot \mathrm{s}^{-1}$ and a RH of 55\%) [35] and Zhengzhou $\left(2.0 \mathrm{~m} \cdot \mathrm{s}^{-1}\right.$ and the RH of 50-65\%) [36] in the North China Plain. This suggested that meteorological conditions were important factors to contribute to heavy haze formation.

\subsection{Characteristics of the Four Pollution Episodes}

The haze episode definition in this study referred to a previous study by Tan, Hu [37]. Briefly, a complete haze episode is defined as the mass concentration of $\mathrm{PM}_{2.5}$ starting from less than $50 \mu \mathrm{g} \cdot \mathrm{m}^{-3}$, up to a peak of more than $100 \mu \mathrm{g} \cdot \mathrm{m}^{-3}$ and subsequently ending at less than $50 \mu \mathrm{g} \cdot \mathrm{m}^{-3}$ again. We obtained four episodes that were 20-24 December 2017 (PE1), 24 December 2017-3 January 2018 (PE2), 3-8 January 2018 (PE3), and 10-17 January 2018 (PE4), respectively. Notably, PE4 was not a complete pollution episode without the concentration of $\mathrm{PM}_{2.5}$ decreasing to less than $50 \mu \mathrm{g} \cdot \mathrm{m}^{-3}$ due to failure sampling after January 17.

The mean mass concentrations of $\mathrm{PM}_{1}, \mathrm{PM}_{2.5}$ and $\mathrm{PM}_{10}$ in the four pollution episodes were in the range of 59.69 to $192.32 \mu \mathrm{g} \cdot \mathrm{m}^{-3}, 79.35$ to $232.37 \mu \mathrm{g} \cdot \mathrm{m}^{-3}, 33.78$ to $122.34 \mu \mathrm{g} \cdot \mathrm{m}^{-3}$, and 59.85 to $257.19 \mu \mathrm{g} \cdot \mathrm{m}^{-3}$, respectively (Figure 2). According to durations and the peak values of $\mathrm{PM}_{2.5}$ (Table 1), the four PEs can be categorized into two short evolution pattern events (lasting for 5-6 days with relatively lower peak $\mathrm{PM}_{2.5}$ concentration for PE1 and PE3) and two long evolution pattern events (lasting for approximately 10 days with higher peak $\mathrm{PM}_{2.5}$ concentration for PE2 and PE4). The $\mathrm{PM}_{2.5}$ to $\mathrm{PM}_{10}$ ratio showed the same increase tendency to all four PEs as the elevation of $\mathrm{PM}_{2.5}$ (from $35.2 \%$ to $60.0 \%$ ), which suggested the predominant contribution of fine particles on the developing of haze pollution. However, compared to a previous study in Beijing [37], the duration of the long evolution pattern was longer (11 vs. 9), but the peak concentrations of $\mathrm{PM}_{2.5}$ were lower than in Beijing ( $\left.250 \mathrm{vs.} 310 \mu \mathrm{g} \cdot \mathrm{m}^{-3}\right)$. This was most likely attributed to the different key chemical compositions and atmospheric chemistry processes between the two cities, especially in the extensity of secondary inorganic and organic formation. 
Table 1. Characteristic of the four pollution episodes.

\begin{tabular}{ccccc}
\hline Pollution Episode & $\mathbf{1}$ & $\mathbf{2}$ & $\mathbf{3}$ & $\mathbf{4}$ \\
\hline Period & $12 / 20-12 / 24$ & $12 / 24-1 / 3$ & $1 / 3-1 / 8$ & $1 / 10-1 / 17$ \\
Duration time (day) & 5 & 11 & 6 & $>8$ \\
Average growth rate of $\mathrm{PM}_{1}\left(\mu \mathrm{g} \cdot \mathrm{m}^{-3} \cdot \mathrm{day}^{-1}\right)$ & 25.0 & 25.2 & 11.6 & 2.1 \\
Average growth rate of $\mathrm{PM}_{2.5}\left(\mu \mathrm{g} \cdot \mathrm{m}^{-3} \cdot \mathrm{day}^{-1}\right)$ & 42.3 & 31.6 & 17.7 & 26.0 \\
Average growth rate of $\mathrm{PM}_{10}\left(\mu \mathrm{g} \cdot \mathrm{m}^{-3} \cdot \mathrm{day}^{-1}\right)$ & 56.8 & 34.8 & 10.2 & 14.5 \\
\hline
\end{tabular}

In order to obtain more information on the four PEs, variation in the growth rate of size-dependent PM in each episode was calculated (Table 1). All three size fractions increased and were comparable in PE1 (25.0, 17.3 and $14.5 \mu \mathrm{g} \cdot \mathrm{m}^{-3}$ for $\mathrm{PM}_{1}, \mathrm{PM}_{1-2.5}$ and $\mathrm{PM}_{2.5-10}$, respectively), while a predominant increase appeared for $\mathrm{PM}_{1}\left(25.2 \mu \mathrm{g} \cdot \mathrm{m}^{-3}\right)$ in PE2. The air mass wiggled between the south of Henan province and the south of Hebei province on 22-23 December in PE1 (Figure S2a), which facilitated the accumulation of PMs transported in the study area. However, the relatively clear and humid air mass from the south on December 27 and stable meteorological conditions appeared on the following December 28 in PE2, which most likely pointed to a heterogenous reaction under high local primary emission (Figure S2b). On the contrary, a predominant increase rate was observed for $\mathrm{PM}_{1}\left(11.6 \mu \mathrm{g} \cdot \mathrm{m}^{-3}\right)$ in PE3, which may be attributed to the aerosol merging effect in ice crystal. Differently, for PE4, the growth rate of $\mathrm{PM}_{2.5}\left(26.0 \mu \mathrm{g} \cdot \mathrm{m}^{-3}\right)$, especially for $\mathrm{PM}_{1-2.5}\left(23.9 \mu \mathrm{g} \cdot \mathrm{m}^{-3}\right)$ was significantly higher than that of $\mathrm{PM}_{10}$ and $\mathrm{PM}_{1}$. This was typically a feature of the secondary reaction and hygroscopic growth of PMs under stagnant conditions with high RH (58.2\%) and low WS $\left(0.82 \mathrm{~m} \cdot \mathrm{s}^{-1}\right)$ (Table S1). The detailed reasons for this will be discussed in Section 3.3. Besides all four PEs, a lasting three days of snowfall was observed on 2-4 January. Subsequently, the $\mathrm{PM}_{2.5-10}$ mass decreased by $75 \%$. The effective clearance of the coarse particles by wet scavenging was consistent with a previous study in Beijing, which showed that the removal effects through precipitation are positive for both $\mathrm{PM}_{2.5}$ and $\mathrm{PM}_{2.5-10}$, and the efficiency is $19.1-68.5 \%$ and $31.7-86.3 \%$, respectively [38].

\subsection{OC and EC Fractions}

The average mass concentration of carbonaceous components (OC and EC) in $\mathrm{PM}_{1}, \mathrm{PM}_{2.5}$ and $\mathrm{PM}_{10}$ were 11.37 and $5.87,19.24$ and $7.36 \mu \mathrm{g} \cdot \mathrm{m}^{-3}$, and 27.04 and $10.27 \mu \mathrm{g} \cdot \mathrm{m}^{-3}$ during the whole sampling days, respectively (Figure 3). For the four PEs, both the mean OC and EC concentrations of $\mathrm{PM}_{1}, \mathrm{PM}_{2.5}$ and $\mathrm{PM}_{10}$ in PE3 were the lowest, with values in range of 6.59 to $12.39 \mu \mathrm{g} \cdot \mathrm{m}^{-3}$ and $3.60-6.41 \mu \mathrm{g} \cdot \mathrm{m}^{-3}$, respectively. While both $\mathrm{OC}$ and EC values were comparable in other three PEs, with values approximately double that in PE3 (Table 2). The proportion of TAC (TAC $=\mathrm{OM}+\mathrm{EC}, \mathrm{OM}$ (organic matter) $=1.6 \times \mathrm{OC}[39]$ ) in $\mathrm{PM}_{1}, \mathrm{PM}_{2.5}$ and $\mathrm{PM}_{10}$ ranged from $25.4 \%$ to $59.7 \%, 17.2 \%$ to $58.1 \%$, and $11.1 \%$ to $38.7 \%$, with an average proportion of $43 \%, 36 \%$ and $26 \%$, respectively. The decreasing trend with particle size increasement was consistent to that in previous study, which reported TAC accounted for $59.2 \%$ of $\mathrm{PM}_{0.1}$, while it was $44.6 \%$ and $43.8 \%$ of $\mathrm{PM}_{2.5}$ and $\mathrm{PM}_{10}$ in Vietnam [40]. The variation in size-dependent OC and EC concentration in these four PEs are discussed in the following three sections. 


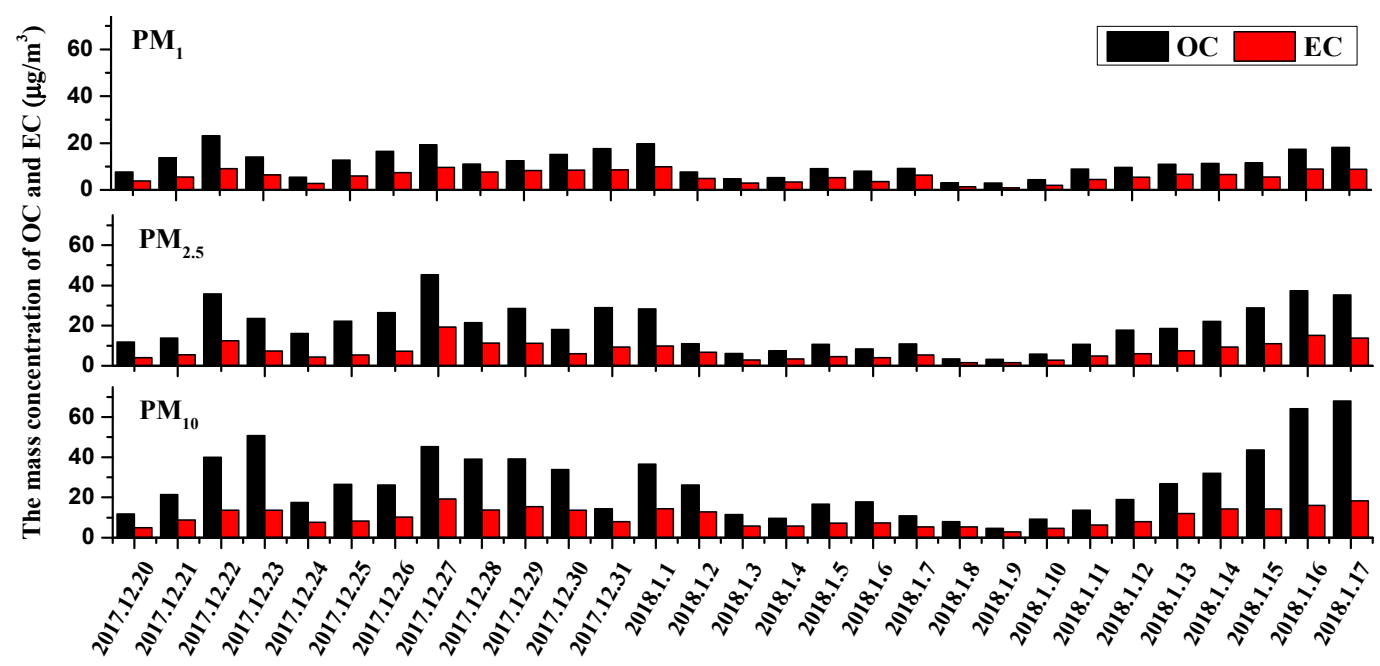

Figure 3. The mass concentration of $\mathrm{OC}$ and $\mathrm{EC}$ in $\mathrm{PM}_{1}, \mathrm{PM}_{2.5}$ and $\mathrm{PM}_{10}$ during the sampling days.

Table 2. Concentration and range of carbonaceous components in $\mathrm{PM}_{1}, \mathrm{PM}_{2.5}$ and $\mathrm{PM}_{10}$ in the four PEs.

\begin{tabular}{ccccccccccccc}
\hline \multirow{2}{*}{ PE } & \multicolumn{3}{c}{ PE1 } & \multicolumn{3}{c}{ PE2 } & \multicolumn{3}{c}{ PE3 } & \multicolumn{3}{c}{ PE4 } \\
\cline { 2 - 13 } & $\mathbf{P M}_{\mathbf{1}}$ & $\mathbf{P M}_{\mathbf{2 . 5}}$ & $\mathbf{P M}_{\mathbf{1 0}}$ & $\mathbf{P M}_{\mathbf{1}}$ & $\mathbf{P M}_{\mathbf{2 . 5}}$ & $\mathbf{P M}_{\mathbf{1 0}}$ & $\mathbf{P M}_{\mathbf{1}}$ & $\mathbf{P M}_{\mathbf{2 . 5}}$ & $\mathbf{P M}_{\mathbf{1 0}}$ & $\mathbf{P M}_{\mathbf{1}}$ & $\mathbf{P M}_{\mathbf{2 . 5}}$ & $\mathbf{P M}_{\mathbf{1 0}}$ \\
\hline $\mathrm{TC}\left(\mu \mathrm{g} \cdot \mathrm{m}^{-3}\right)$ & 18.29 & 26.92 & 37.78 & 19.90 & 31.62 & 40.50 & 10.46 & 11.46 & 18.52 & 17.57 & 30.82 & 46.26 \\
OC $\left(\mu \mathrm{g} \cdot \mathrm{m}^{-3}\right)$ & 11 & 20.23 & 28.33 & 12.95 & 23.07 & 28.75 & 6.59 & 7.86 & 12.39 & 11.52 & 22.03 & 34.54 \\
EC $\left(\mu \mathrm{g} \cdot \mathrm{m}^{-3}\right)$ & 5.54 & 6.71 & 9.70 & 6.95 & 8.54 & 11.76 & 3.60 & 3.87 & 6.14 & 6.06 & 8.79 & 11.72 \\
POC $\left(\mu \mathrm{g} \cdot \mathrm{m}^{-3}\right)$ & 8.07 & 10.87 & 14.38 & 10.13 & 13.83 & 17.43 & 5.63 & 5.83 & 9.10 & 8.82 & 14.23 & 17.37 \\
PC $\left(\mu \mathrm{g} \cdot \mathrm{m}^{-3}\right)$ & 13.52 & 17.58 & 24.08 & 17.08 & 22.37 & 29.19 & 9.23 & 9.7 & 15.24 & 14.88 & 23.02 & 29.09 \\
SOC $\left(\mu \mathrm{g} \cdot \mathrm{m}^{-3}\right)$ & 4.69 & 9.36 & 13.95 & 3.11 & 10.17 & 11.32 & 0.96 & 2.03 & 3.95 & 2.69 & 7.80 & 17.18 \\
SOC/OC & $34 \%$ & $46 \%$ & $45 \%$ & $19 \%$ & $38 \%$ & $37 \%$ & $15 \%$ & $26 \%$ & $23 \%$ & $23 \%$ & $34 \%$ & $42 \%$ \\
TAC/PM & $46 \%$ & $51 \%$ & $28 \%$ & $36 \%$ & $37 \%$ & $26 \%$ & $46 \%$ & $24 \%$ & $23 \%$ & $44 \%$ & $32 \%$ & $26 \%$ \\
OC/EC & 2.22 & 3.06 & 2.77 & 1.85 & 2.83 & 2.42 & 1.80 & 2.19 & 1.98 & 1.92 & 2.48 & 2.72 \\
Char-EC/Soot-EC & 6.97 & 7.88 & 6.77 & 6.54 & 6.87 & 10.13 & 4.74 & 4.24 & 5.39 & 6.82 & 10.67 & 8.52 \\
\hline
\end{tabular}

\subsubsection{Effect of PMs Accumulation by Transportation and Local Emission in PE1 and PE2}

The growth rates of OC in PE1 were comparable for $\mathrm{PM}_{1}$ and $\mathrm{PM}_{1-2.5}$, with values of 5.18 and $2.84 \mu \mathrm{g} \cdot \mathrm{m}^{-3} \cdot$ day $^{-1}$, respectively (Table 3), which come up to $21 \%$ and $16 \%$ of the mass growth rates of $\mathrm{PM}_{1}$ and $\mathrm{PM}_{1-2.5}$. The values increased up to $27 \%$ and $23 \%$ if we calculated TC growth rate to $\mathrm{PM}_{1}$ and $\mathrm{PM}_{1-2.5}$ mass. Interestingly, the percentages of $\mathrm{TC}$ in $\mathrm{PM}_{1}$ and $\mathrm{PM}_{1-2.5}$ mass were $30 \%$ and $24 \%$, respectively, on the day of peak concentration. Additionally, the three sizes of PM mass concentration had similar increase rates. All this does not seem to take place chemical reaction rather than a physical process. Considering that the air mass wiggled on 23 December in PE1 combined with SOC increasing in $\mathrm{PM}_{1}$ fraction, we confidently speculated that a strong aerosol aging process took place during fully mixing with the polluted air from the south of Henan, west of Shandong and south of Hebei in PE1 (Figure S2a). In addition, the proportion of the four components of OC (OC1, OC2, OC3 and OC4) in TC during the formation of pollution was relatively stable in PE1 (Figure 4; since the content of EC3 and optical pyrolyzed OC (py) components are too low and the proportions are negligible, they are not in consideration), which was also a partly proof of the full mixing effect of air masses. 
Table 3. The growth rate of OC, SOC, POC and $\mathrm{PC}$ of $\mathrm{PM}_{1}, \mathrm{PM}_{2.5}$ and $\mathrm{PM}_{10}$ in 4 PEs.

\begin{tabular}{cccccc}
\hline & Sizes & PE1 & PE2 & PE3 & PE4 \\
\hline \multirow{3}{*}{ Average growth rate of OC $\left(\mu \mathrm{g} \cdot \mathrm{m}^{-3} \cdot \mathrm{day}^{-1}\right)$} & $\mathrm{PM}_{1}$ & 5.18 & 3.67 & 2.27 & 1.75 \\
& $\mathrm{PM}_{2.5}$ & 8.02 & 3.47 & 1.54 & 3.99 \\
& $\mathrm{PM}_{10}$ & 9.31 & 2.89 & 1.70 & 3.27 \\
\hline \multirow{3}{*}{ Average growth rate of SOC $\left(\mu \mathrm{g} \cdot \mathrm{m}^{-3} \cdot \mathrm{day}^{-1}\right)$} & $\mathrm{PM}_{1}$ & 2.65 & 1.46 & 0.27 & 0.12 \\
& $\mathrm{PM}_{2.5}$ & 3.47 & 1.93 & 0.60 & 2.27 \\
& $\mathrm{PM}_{10}$ & 5.03 & 1.58 & 0.99 & 1.66 \\
\hline \multirow{2}{*}{ Average growth rate of POC $\left(\mu \mathrm{g} \cdot \mathrm{m}^{-3} \cdot \mathrm{day}^{-1}\right)$} & $\mathrm{PM}_{1}$ & 2.53 & 2.22 & 1.19 & 1.63 \\
& $\mathrm{PM}_{2.5}$ & 4.55 & 1.54 & 0.94 & 1.72 \\
& $\mathrm{PM}_{10}$ & 4.64 & 1.30 & 0.71 & 1.61 \\
\hline \multirow{2}{*}{ Average growth rate of PC $\left(\mu \mathrm{g} \cdot \mathrm{m}^{-3} \cdot \mathrm{day}^{-1}\right)$} & $\mathrm{PM}_{1}$ & 4.27 & 4.21 & 1.67 & 2.42 \\
& $\mathrm{PM}_{2.5}$ & 7.36 & 9.85 & 1.29 & 4.67 \\
& $\mathrm{PM}_{10}$ & 7.27 & 7.27 & 0.99 & 4.27 \\
\hline
\end{tabular}

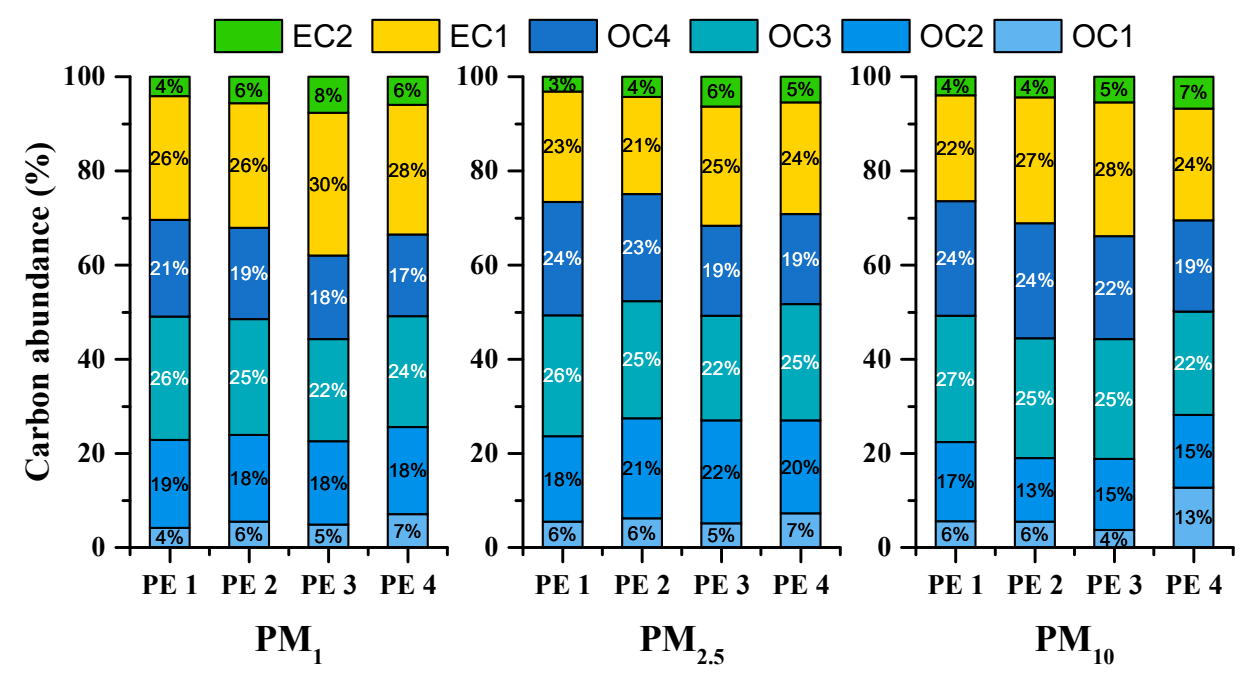

Figure 4. The percentage contributions (to TC) of eight carbon fractions in $\mathrm{PM}_{1}, \mathrm{PM}_{2.5}$ and $\mathrm{PM}_{10}$ when $\mathrm{PM}_{2.5}$ exceeded $100 \mu \mathrm{g} \cdot \mathrm{m}^{-3}$ during the pollution formation of the four PEs.

EC and POC are both mainly produced by primary emissions [41-43]. Therefore, summation of EC and POC could be regarded as the primary emission carbon (PC). The mean PC concentrations were $17.08,22.37$ and $29.19 \mu \mathrm{g} \cdot \mathrm{m}^{-3}$ for $\mathrm{PM}_{1}, \mathrm{PM}_{2.5}$ and $\mathrm{PM}_{10}$, respectively. The concentration as well as the growth rate of PC in PE2 was clearly higher $\left(4.21\right.$ in $\mathrm{PM}_{1}, 9.85 \mu \mathrm{g} \cdot \mathrm{m}^{-3} \cdot \mathrm{day}^{-1}$ in $\mathrm{PM}_{2.5}$ and $7.27 \mu \mathrm{g} \cdot \mathrm{m}^{-3} \cdot \mathrm{day}^{-1}$ in $\mathrm{PM}_{10}$, respectively) (Table 3). Eventually, the ratios of TC to PM were $20 \%$ and $35 \%$ in the day with peak $\mathrm{PM}_{1}$ and $\mathrm{PM}_{2.5}$ mass concentration, with $81 \%$ and $78 \%$ contribution from PC. These indicated that local primary emission pollution has an important contribution to the formation of PE2. Through higher ratios of Char-EC/Soot-EC (ranging from 2.93 to $11.17 \mu \mathrm{g} \cdot \mathrm{m}^{-3}$ for $\mathrm{PM}_{1}, 2.38$ to $18.67 \mu \mathrm{g} \cdot \mathrm{m}^{-3}$ for $\mathrm{PM}_{2.5}$, and 4.95 to $17.04 \mu \mathrm{g} \cdot \mathrm{m}^{-3}$ for $\mathrm{PM}_{10}$, with an average ratio of $6.54,6.87$ and $10.13 \mu \mathrm{g} \cdot \mathrm{m}^{-3}$, respectively) (Table 2), we speculated that the incomplete combustion process from heating, such as biomass burning [44-46], or the difference in coal types, such as bituminous coal [46], need to be paid more attention in the controlling strategy. In summary, these results highlighted the accumulation effect on transportation and local primary emission under low RH condition.

\subsubsection{Effect of Photochemical Reaction and Hygroscopic Growth in PE3 and PE4}

Different to PE1 and PE2, the RH was relatively higher in PE3 and PE4. Carbonaceous components were predominantly in $\mathrm{PM}_{1}$, accounting to $37 \%$ and $39 \%$ in the day with peak $\mathrm{PM}_{1}$ mass concentration in PE3 and PE4, respectively. For PE3, it started after a snowfall. The temperature was below $0{ }^{\circ} \mathrm{C}$ 
and $\mathrm{RH}$ was $84 \%$. In ice dominant condition, carbon components as ice cores could grow through ice collision, leading to aerosol aging [47]. This maybe the reason we overserved such high contribution of TC to $\mathrm{PM}_{1}$ mass. However, the situation changed in $\mathrm{PM}_{1-2.5}$, with only $2 \%$ contribution to $\mathrm{PM}$ increasement. Considering high $\mathrm{RH}$ and more radiation in clear air, a strong photochemical reaction or heterogenous reaction with $\mathrm{SO}_{2}$ or $\mathrm{NO}_{2}$ took place, which contributed to the fast increase of $\mathrm{PM}_{2.5}$.

In PE4, carbonaceous components contributed to $13 \% \mathrm{PM}_{2.5}$ increasement. Although it was higher than that of PE3, it was 46-63\% lower than that of PE1 and PE2. Moreover, the SOC growth rates were predominantly in $\mathrm{PM}_{2.5}$ with a value of $2.27 \mu \mathrm{g} \cdot \mathrm{m}^{-3} \cdot$ day $^{-1}$ (Table 3). Although an increase in SOC dominance occurred in $\mathrm{PM}_{2.5}$, the low percentile of SOC to $\mathrm{PM}_{2.5}$ did not seem to contribute to such an explosive growth in $\mathrm{PM}_{2.5}$ mass. Other components should contribute more in PE4, such as secondary inorganic aerosol through heterogenous reaction and hygroscopic growth. A previous study revealed that the particle size rapidly increased when the relative humidity exceeded $50 \%$ [48]. The liquid water not only satisfied the demand for the hygroscopic growth of PM, but also facilitated heterogeneous reactions for forming more secondary aerosols, and subsequently accelerating hygroscopic growth, eventually accounting for $48 \%$ of the total secondary organic aerosols [49]. In PE4, the average wind speed was $0.82 \mathrm{~m} \cdot \mathrm{s}^{-1}$ and the average relative humidity was $58.2 \%$. Long-term stagnant and high-humidity meteorology conditions promoted the non-carbonaceous components to grow into $\mathrm{PM}_{1-2.5}$ through hygroscopic growth. In summary, these above clues strongly point to the influence of hygroscopic growth of PM and the heterogeneous secondary reaction from non-carbonaceous components on the formation of haze in suitable RH condition.

\subsubsection{Effect of Wet Scavenging}

When the emission of pollution sources was stable, meteorological conditions were the important factors that affected the concentration of PM and its components, such as the atmospheric self-cleaning processes by rainfall or snowfall [50]. The scavenging activity of snowfall is a crucial indicator of air quality improvement in winter. In 2-4 January 2018, a moderate snowfall was observed in Xinxiang lasting for three days. It is clearly showed that both OC and EC had low concentrations in PE3 (Table 2). In particular, the concentration of OC significantly decreased on 2-4 January (Figure 3). In order to visually show the wet scavenging effect of snowfall on PE3, three days before snowfall and other days in PE3 was used as the pre-snowfall and snowfall period to calculate the clearance rate. The clearance rates of OC and EC were $65 \%$ and $59 \%$ for $\mathrm{PM}_{1}, 67 \%$ and $49 \%$ for $\mathrm{PM}_{2.5}$, and $44 \%$ and $32 \%$ for $\mathrm{PM}_{10}$, respectively. The carbonaceous components in $\mathrm{PM}_{1}$ had the highest clearance rate, but as for the PM mass concentration, $\mathrm{PM}_{10}$ had the highest clearance rate $\left(59 \%\right.$ for $\mathrm{PM}_{1}, 64 \%$ for $\mathrm{PM}_{2.5}$ and $73 \%$ for $\mathrm{PM}_{10}$ ), which indicated that wet scavenging could effectively remove coarse particles and that $\mathrm{OC}$ was not predominant components in $\mathrm{PM}_{10}$. In addition, we estimated the clearance rates of POC and SOC to further elucidate wet scavenging effect on OC. The clearance rates of POC and SOC were $59 \%$ and $90 \%$ for $\mathrm{PM}_{1}, 49 \%$ and $85 \%$ for $\mathrm{PM}_{2.5}$, and $32 \%$ and $64 \%$ for $\mathrm{PM}_{10}$, respectively. The clearance trends of POC and SOC for the three sizes were similar to that of OC. Notably, more than $85 \%$ of SOC was removed in $\mathrm{PM}_{1}$ and $\mathrm{PM}_{2.5}$ through wet cleansing while $\mathrm{POC}$ was not. This most likely related to the fact that SOC was composed of more hydrophilic components [50-54]. Witkowska [51] found that precipitation was the most effective form of atmospheric cleansing of water soluble organic carbon (WSOC) contained in $\mathrm{PM}_{1}$ and $\mathrm{PM}_{2.5}$ aerosols, and snow and rain cleaned WSOC more effectively when precipitation lasted longer than $24 \mathrm{~h}$. Accordingly, it has been reported that $10-80 \%$ of the OC in aerosols is composed of WSOC [52-54]. On mid-latitude areas, wet deposition can remove as much as $80 \%$ of the carbonaceous aerosols [55]. Compared with OC, the influence of snowfall events on the EC concentration was relatively lower, which may relate to that $\mathrm{EC}$ has a longer atmospheric residence time than $\mathrm{OC}$ as its smaller size $[56,57]$. 


\section{Conclusions}

The daily mean mass concentration of $\mathrm{PM}_{1}, \mathrm{PM}_{2.5}$, and $\mathrm{PM}_{10}$ were $63.20,119.63$ and $211.95 \mu \mathrm{g} \cdot \mathrm{m}^{-3}$, respectively. The average mass concentrations of $\mathrm{OC}$ and $\mathrm{EC}$ in $\mathrm{PM}_{1}, \mathrm{PM}_{2.5}$ and $\mathrm{PM}_{10}$ were 11.37 and 5.87, 19.24 and 7.36, and 27.04 and $10.27 \mu \mathrm{g} \cdot \mathrm{m}^{-3}$, respectively. The average proportions of TM for the three particle sizes of $\mathrm{PM}_{1}, \mathrm{PM}_{2.5}$ and $\mathrm{PM}_{10}$ were $43 \%, 36 \%$ and $26 \%$, respectively. These results revealed that the carbonaceous components in fine particles is high, and decrease along with the increase in particle size.

These four episodes were categorized as a short evolution pattern (PE1 and PE3) and a long evolution pattern (PE2 and PE4). Unstable metrological conditions, such as air mass frequently fluctuating or heavy wind blowing, was the main reason for the short evolution pattern. In comparison, stagnant condition facilities to atmospheric chemical reaction, which would last for more days in long evolution pattern. Carbonaceous components contributed to PE1 and PE2 under drier conditions through transportation and local combustion emission, while they were not main species in PE3 and PE4 for haze explosive growth under suitable $\mathrm{RH}$, whether for the short or long evolution pattern. These results highlight that local primary emissions such as biomass combustion were important sources of haze formation in Central China, especially in dry conditions.

Supplementary Materials: The following are available online at http://www.mdpi.com/2076-3417/10/10/3498/s1, Figure S1: Mass concentration of $\mathrm{PM}_{2.5}$ and meteorological conditions (wind speed and relative humidity) during sampling period, Figure S2: The backward air mass trajectories of $48 \mathrm{~h}$ starting form Xinxiang, (a) for PE1, (b) for PE2, (c) for PE3 and (d) for PE4, Table S1: Meteorological parameters during the sampling period.

Author Contributions: Conceptualization, G.Y. and Z.L.; methodology, J.Z.; software, P.Z.; validation, G.Y., Z.L. and Y.W.; formal analysis, G.Y.; investigation, J.Z.; resources, G.Z. and Z.C.; data curation, P.Z.; writing-original draft preparation, J.Z.; writing-review and editing, G.Y. and Z.L.; visualization, G.Y.; supervision, Y.W.; project administration, G.Y.; funding acquisition, G.Y. All authors have read and agreed to the published version of the manuscript.

Funding: This work was funded by the Ministry of Science and Technology of China (grant no. 2017YFC0210000), the National Natural Science Foundation of China (41807327, 41805123), and the Program for Innovative Research Team in Science and Technology in University of Henan Province (No. 20 IRTSTHN011).

Conflicts of Interest: The authors declare no conflict of interest.

\section{References}

1. Harrison, R.M.; Yin, J. Particulate matter in the atmosphere: Which particle properties are important for its effects on health? Sci. Total Environ. 2000, 249, 85-101. [CrossRef]

2. Cifuentes, L.A.; Vega, J.; Kopfer, K.; Lave, L.B. Effect of the fine fraction of particulate matter versus the coarse mass and other pollutants on daily mortality in Santiago, Chile. J. Air Waste Manag. Assoc. (1995) 2000, 50, 1287-1298. [CrossRef] [PubMed]

3. Heyder, J. Deposition of inhaled particles in the human respiratory tract and consequences for regional targeting in respiratory drug delivery. Proc. Am. Thorac. Soc. 2004, 1, 315-320. [CrossRef] [PubMed]

4. Trippetta, S.; Caggiano, R.; Telesca, L. Analysis of particulate matter in anthropized areas characterized by the presence of crude oil pre-treatment plants: The case study of the Agri Valley (Southern Italy). Atmos. Environ. 2013, 77, 105-116. [CrossRef]

5. Morawska, L.; Keogh, D.U.; Thomas, S.B.; Mengersen, K. Modality in ambient particle size distributions and its potential as a basis for developing air quality regulation. Atmos. Environ. 2008, 42, 1617-1628. [CrossRef]

6. Ye, B.; Ji, X.; Yang, H.; Yao, X.; Chan, C.K.; Cadle, S.H.; Chan, T.; Mulawa, P.A. Concentration and chemical composition of PM2.5 in Shanghai for a 1-year period. Atmos. Environ. 2003, 37, 499-510. [CrossRef]

7. Liu, X.; Zhang, Y.-L.; Peng, Y.; Xu, L.; Zhu, C.; Cao, F.; Zhai, X.; Haque, M.M.; Yang, C.; Chang, Y.; et al. Chemical and optical properties of carbonaceous aerosols in Nanjing, eastern China: Regionally transported biomass burning contribution. Atmos. Chem. Phys. 2019, 19, 11213-11233. [CrossRef] 
8. Ji, D.; Gao, W.; Maenhaut, W.; He, J.; Wang, Z.; Li, J.; Du, W.; Wang, L.; Sun, Y.; Xin, J.; et al. Impact of air pollution control measures and regional transport on carbonaceous aerosols in fine particulate matter in urban Beijing, China: Insights gained from long-term measurement. Atmos. Chem. Phys. 2019, 19, 8569-8590. [CrossRef]

9. Kaushal, D.; Kumar, A.; Yadav, S.; Tandon, A.; Attri, A.K. Wintertime carbonaceous aerosols over Dhauladhar region of North-Western Himalayas. Environ. Sci. Pollut. Res. 2018, 25, 8044-8056. [CrossRef]

10. Zhang, G.H.; Bi, X.H.; Chan, L.Y.; Wang, X.M.; Sheng, G.Y.; Fu, J.M. Size-segregated chemical characteristics of aerosol during haze in an urban area of the Pearl River Delta region, China. Urban Clim. 2013, 4, 74-84. [CrossRef]

11. Wang, Y.Q.; Zhang, X.Y.; Gong, S.L.; Zhou, C.H.; Hu, X.Q.; Liu, H.L.; Niu, T.; Yang, Y.Q. Surface observation of sand and dust storm in East Asia and its application in CUACE/Dust. Atmos. Chem. Phys. 2008, 8, 545-553. [CrossRef]

12. Zhan, C.L.; Zhang, J.Q.; Zheng, J.R.; Yao, R.Z.; Wang, P.; Liu, H.X.; Xiao, W.S.; Liu, X.L.; Cao, J.J. Characterization of carbonaceous fractions in PM2.5 and PM10 over a typical industrial city in central China. Environ. Sci. Pollut. Res. 2019, 26, 16855-16867. [CrossRef] [PubMed]

13. Wang, Y.Q.; Zhang, X.Y.; Sun, J.Y.; Zhang, X.C.; Che, H.Z.; Li, Y. Spatial and temporal variations of the concentrations of PM10, PM2.5 and PM1 in China. Atmos. Chem. Phys. Discuss. 2015, 15, 3585-13598. [CrossRef]

14. Deng, X.; Cao, W.; Huo, Y.; Yang, G.; Yu, C.; He, D.; Deng, W.; Fu, W.; Ding, H.; Zhai, J.; et al. Meteorological conditions during a severe, prolonged regional heavy air pollution episode in eastern China from December 2016 to January 2017. Theor. Appl. Climatol. 2019, 135, 1105-1122. [CrossRef]

15. Ye, S.; Ma, T.; Duan, F.; Li, H.; He, K.; Xia, J.; Yang, S.; Zhu, L.; Ma, Y.; Huang, T.; et al. Characteristics and formation mechanisms of winter haze in Changzhou, a highly polluted industrial city in the Yangtze River Delta, China. Environ. Pollut. 2019, 253, 377-383. [CrossRef] [PubMed]

16. Cao, J.J.; Lee, S.C.; Ho, K.F.; Zou, S.C.; Fung, K.; Li, Y.; Watson, J.G.; Chow, J.C. Spatial and seasonal variations of atmospheric organic carbon and elemental carbon in Pearl River Delta Region, China. Atmos. Environ. 2004, 38, 4447-4456. [CrossRef]

17. Cao, J.J.; Wu, F.; Chow, J.C.; Lee, S.C.; Li, Y.; Chen, S.W.; An, Z.S.; Fung, K.K.; Watson, J.G.; Zhu, C.S.; et al. Characterization and source apportionment of atmospheric organic and elemental carbon during fall and winter of 2003 in Xi'an, China. Atmos. Chem. Phys. 2005, 5, 3127-3137. [CrossRef]

18. Cao, J.J.; Lee, S.C.; Chow, J.C.; Watson, J.G.; Ho, K.F.; Zhang, R.J.; Jin, Z.D.; Shen, Z.X.; Chen, G.C.; Kang, Y.M.; et al. Spatial and seasonal distributions of carbonaceous aerosols over China. J. Geophys. Res. Atmos. 2007, 112. [CrossRef]

19. Lim, S.; Lee, M.; Lee, G.; Kim, S.; Yoon, S.; Kang, K. Ionic and carbonaceous compositions of PM10, PM2.5 and PM1.0 at Gosan ABC Superstation and their ratios as source signature. Atmos. Chem. Phys. 2012, 12, 2007-2024. [CrossRef]

20. Vedal, S. Ambient Particles and Health: Lines that Divide. J. Air Waste Manag. Assoc. 1997, 47, 551-581. [CrossRef]

21. Jacobson, M.Z. Strong radiative heating due to mixing state of black carbon in atmospheric aerosol. Nature 2001, 409, 695-697. [CrossRef] [PubMed]

22. Duan, F.; Liu, X.; Tong, Y.; Cachier, H. Identification and estimate of biomass burning contribution to the urban aerosol organic carbon concentrations in Beijing. Atmos. Environ. 2004, 38, 1275-1282. [CrossRef]

23. Pankow, J.F. An absorption model of the gas/aerosol partitioning involved in the formation of secondary organic aerosol. Atmos. Environ. 2007, 41, S75-S79. [CrossRef]

24. Decesari, S.; Facchini, M.C.; Fuzzi, S.; McFiggans, G.B.; Coe, H.; Bower, K.N. The water-soluble organic component of size-segregated aerosol, cloud water and wet depositions from Jeju Island during ACE-Asia. Atmos. Environ. 2005, 39, 211-222. [CrossRef]

25. Feng, J.L.; Yu, H.; Mi, K.; Su, X.F.; Li, Y.; Li, Q.L.; Sun, J.H. One year study of PM2.5 in Xinxiang city, North China: Seasonal characteristics, climate impact and source. Ecotoxicol. Environ. Saf. 2018, 154, 75-83. [CrossRef] [PubMed]

26. Feng, J.; Yu, H.; Liu, S.; Su, X.; Li, Y.; Pan, Y.; Sun, J. PM2.5 levels, chemical composition and health risk assessment in Xinxiang, a seriously air-polluted city in North China. Environ. Geochem. Health 2017, 39, 1071-1083. [CrossRef] 
27. Dai, Q.; Bi, X.; Liu, B.; Li, L.; Ding, J.; Song, W.; Bi, S.; Schulze, B.C.; Song, C.; Wu, J.; et al. Chemical nature of PM2.5 and PM10 in Xi'an, China: Insights into primary emissions and secondary particle formation. Environ. Pollut. 2018, 240, 155-166. [CrossRef]

28. Han, Y.M.; Cao, J.J.; Chow, J.C.; Watson, J.G.; An, Z.S.; Jin, Z.D.; Fung, K.; Liu, S.X. Evaluation of the thermal/optical reflectance method for discrimination between char- and soot-EC. Chemosphere 2007, 69, 569-574. [CrossRef]

29. Li, J.J.; Shen, Z.X.; Tong, Z.; Cao, J.J.; Han, Y.M.; Liu, S.X.; Zhu, C.S. Day-night variation of carbonaceous aerosols in PM10 during winter and spring over Xi'an. Huan Jing Ke Xue Huanjing Kexue 2009, 30, 1506-1513.

30. Turpin, B.J.; Huntzicker, J.J. Identification of secondary organic aerosol episodes and quantitation of primary and secondary organic aerosol concentrations during SCAQS. Atmos. Environ. 1995, 29, 3527-3544. [CrossRef]

31. Castro, L.M.; Pio, C.A.; Harrison, R.M.; Smith, D.J.T. Carbonaceous aerosol in urban and rural European atmospheres: Estimation of secondary organic carbon concentrations. Atmos. Environ. 1999, 33, 2771-2781. [CrossRef]

32. Turpin, B.J.; Huntzicker, J.J. Secondary formation of organic aerosol in the Los Angeles basin: A descriptive analysis of organic and elemental carbon concentrations. Atmos. Environ. Part A Gen. Top. 1991, 25, $207-215$. [CrossRef]

33. Ye, W.F.; Ma, Z.Y.; Ha, X.Z. Spatial-temporal patterns of PM2.5 concentrations for 338 Chinese cities. Sci. Total Environ. 2018, 631-632, 524-533. [CrossRef] [PubMed]

34. Sun, Y.L.; Wang, Z.F.; Fu, P.Q.; Jiang, Q.; Yang, T.; Li, J.; Ge, X.L. The impact of relative humidity on aerosol composition and evolution processes during wintertime in Beijing, China. Atmos. Environ. 2013, 77, 927-934. [CrossRef]

35. Luo, Y.Y.; Zhou, X.H.; Zhang, J.Z.; Xiao, Y.; Wang, Z.; Zhou, Y.; Wang, W.X. PM2.5 pollution in a petrochemical industry city of northern China: Seasonal variation and source apportionment. Atmos. Res. 2018, 212, 285-295. [CrossRef]

36. Jiang, N.; Duan, S.G.; Yu, X.; Zhang, R.Q.; Wang, K. Comparative major components and health risks of toxic elements and polycyclic aromatic hydrocarbons of PM2.5 in winter and summer in Zhengzhou: Based on three-year data. Atmos. Res. 2018, 213, 173-184. [CrossRef]

37. Tan, T.; Hu, M.; Li, M.; Guo, Q.; Wu, Y.; Fang, X.; Gu, F.; Wang, Y.; Wu, Z. New insight into PM2.5 pollution patterns in Beijing based on one-year measurement of chemical compositions. Sci. Total Environ. 2018, 621, 734-743. [CrossRef]

38. Zheng, Z.; Xu, G.; Li, Q.; Chen, C.; Li, J. Effect of precipitation on reducing atmospheric pollutant over Beijing. Atmos. Pollut. Res. 2019, 10, 1443-1453. [CrossRef]

39. Li, B.; Zhang, J.; Zhao, Y.; Yuan, S.; Zhao, Q.; Shen, G.; Wu, H. Seasonal variation of urban carbonaceous aerosols in a typical city Nanjing in Yangtze River Delta, China. Atmos. Environ. 2015, 106, 223-231. [CrossRef]

40. Thuy, N.T.T.; Dung, N.T.; Sekiguchi, K.; Thuy, L.B.; Hien, N.T.T.; Yamaguchi, R. Mass Concentrations and Carbonaceous Compositions of PM0.1, PM2.5, and PM10 at Urban Locations of Hanoi, Vietnam. Aerosol Air Qual. Res. 2018, 18, 1591-1605. [CrossRef]

41. Hu, W.W.; Hu, M.; Deng, Z.Q.; Xiao, R.; Kondo, Y.; Takegawa, N.; Zhao, Y.J.; Guo, S.; Zhang, Y.H. The characteristics and origins of carbonaceous aerosol at a rural site of PRD in summer of 2006. Atmos. Chem. Phys. 2012, 12, 1811-1822. [CrossRef]

42. Lim, H.-J.; Turpin, B.J. Origins of primary and secondary organic aerosol in Atlanta: Results of time-resolved measurements during the Atlanta Supersite Experiment. Environ. Sci. Technol. 2002, 36, 4489-4496. [CrossRef] [PubMed]

43. Lin, P.; Hu, M.; Deng, Z.; Slanina, J.; Han, S.; Kondo, Y.; Takegawa, N.; Miyazaki, Y.; Zhao, Y.; Sugimoto, N. Seasonal and diurnal variations of organic carbon in PM2.5 in Beijing and the estimation of secondary organic carbon. J. Geophys. Res. Atmos. 2009, 114. [CrossRef]

44. Cao, J.J.; Zhu, C.S.; Tie, X.X.; Geng, F.H.; Xu, H.M.; Ho, S.S.H.; Wang, G.H.; Han, Y.M.; Ho, K.F. Characteristics and sources of carbonaceous aerosols from Shanghai, China. Atmos. Chem. Phys. 2013, 13, 803-817. [CrossRef]

45. Chow, J.C.; Watson, J.G.; Chen, L.W.A.; Arnott, W.P.; Moosmuller, H.; Fung, K. Equivalence of elemental carbon by thermal/optical reflectance and transmittance with different temperature protocols. Environ. Sci. Technol. 2004, 38, 4414-4422. [CrossRef] [PubMed] 
46. Han, Y.M.; Cao, J.J.; Lee, S.C.; Ho, K.F.; An, Z.S. Different characteristics of char and soot in the atmosphere and their ratio as an indicator for source identification in Xi'an, China. Atmos. Chem. Phys. 2010, 10, $595-607$. [CrossRef]

47. Ding, S.; Zhao, D.; He, C.; Huang, M.; He, H.; Tian, P.; Bi, K.; Liu, Q.; Yu, C.; Pitt, J.; et al. Observed Interactions Between Black Carbon and Hydrometeor During Wet Scavenging in Mixed-Phase Clouds. Geophys. Res. Lett. 2019, 46. [CrossRef]

48. McMurry, P.H.; Stolzenburg, M.R. On the sensitivity of particle size to relative humidity for Los Angeles aerosols. Atmos. Environ. (1967) 1989, 23, 497-507. [CrossRef]

49. Wu, J.; Bei, N.; Hu, B.; Liu, S.; Zhou, M.; Wang, Q.; Li, X.; Liu, L.; Feng, T.; Liu, Z.; et al. Is water vapor a key player of the wintertime haze in North China Plain? Atmos. Chem. Phys. 2019, 19, 8721-8739. [CrossRef]

50. Tie, X.; Zhang, Q.; He, H.; Cao, J.; Han, S.; Gao, Y.; Li, X.; Jia, X.C. A budget analysis of the formation of haze in Beijing. Atmos. Environ. 2015, 100, 25-36. [CrossRef]

51. Witkowska, A.; Lewandowska, A.U. Water soluble organic carbon in aerosols (PM1, PM2.5, PM10) and various precipitation forms (rain, snow, mixed) over the southern Baltic Sea station. Sci. Total Environ. 2016, 573, 337-346. [CrossRef]

52. Zhang, Y.L.; Liu, J.W.; Salazar, G.A.; Li, J.; Zotter, P.; Zhang, G.; Shen, R.R.; Sch, K.; Schnelle-Kreis, J.; Prév, A.S.H. Micro-scale $(\mu \mathrm{g})$ radiocarbon analysis of water-soluble organic carbon in aerosol samples. Atmos. Environ. 2014, 97, 1-5. [CrossRef]

53. Lopes, S.P.; Matos, J.T.V.; Silva, A.M.S.; Duarte, A.C.; Duarte, R.M.B.O. H-1 NMR studies of water- and alkaline-soluble organic matter from finen urban atmospheric aerosols. Atmos. Environ. 2015, 119, 374-380. [CrossRef]

54. Qiao, T.; Zhao, M.; Xiu, G.; Yu, J. Seasonal variations of water soluble composition (WSOC, Hulis and WSIIs) in PM1 and its implications on haze pollution in urban Shanghai, China. Atmos. Environ. 2015, 123, 306-314. [CrossRef]

55. Pan, Y.P.; Wang, Y.S. Atmospheric wet and dry deposition of trace elements at 10 sites in Northern China. Atmos. Chem. Phys. 2015, 15, 951-972. [CrossRef]

56. Lim, H.J.; Turpin, B.J.; Russell, L.M.; Bates, T.S. Organic and elemental carbon measurements during ACE-Asia suggest a longer atmospheric lifetime for elemental carbon. Environ. Sci. Technol. 2003, 37, 3055-3061. [CrossRef] [PubMed]

57. Niu, Z.; Zhang, F.; Chen, J.; Yin, L.; Wang, S.; Xu, L. Carbonaceous species in PM2.5 in the coastal urban agglomeration in the Western Taiwan Strait Region, China. Atmos. Res. 2013, 122, 102-110. [CrossRef] 